\title{
Leukoencephalopathy with accumulated succinate is indicative of SDHAF1 related complex II deficiency
}

Andreas Ohlenbusch ${ }^{1 *+}$, Simon Edvardson ${ }^{2}$, Johannes Skorpen ${ }^{3}$, Alf Bjornstad ${ }^{4}$, Ann Saada ${ }^{5}$, Orly Elpeleg ${ }^{5}$, Jutta Gärtner ${ }^{1}$ and Knut Brockmann ${ }^{1 *}$

\begin{abstract}
Background: Deficiency of complex II (succinate dehydrogenase, SDH) represents a rare cause of mitochondrial disease and is associated with a wide range of clinical symptoms. Recently, mutations of SDHAF1, the gene encoding for the SDH assembly factor 1, were reported in SDH-defective infantile leukoencephalopathy. Our goal was to identify SDHAF1 mutations in further patients and to delineate the clinical phenotype.
\end{abstract}

Methods: In a retrospective data collection study we identified nine children with biochemically proven complex II deficiency among our cohorts of patients with mitochondrial disorders. The cohort comprised five patients from three families affected by SDH-defective infantile leukoencephalopathy with accumulation of succinate in disordered cerebral white matter, as detected by in vivo proton MR spectroscopy. One of these patients had neuropathological features of Leigh syndrome. Four further unrelated patients of the cohort showed diverse clinical phenotypes without leukoencephalopathy. SDHAF1 was sequenced in all nine patients.

Results: Homozygous mutations of SDHAF1 were detected in all five patients affected by leukoencephalopathy with accumulated succinate, but not in any of the four patients with other, diverse clinical phenotypes. Two sisters had a mutation reported previously, in three patients two novel mutations were found.

Conclusion: Leukoencephalopathy with accumulated succinate is a key symptom of defective complex II assembly due to SDHAF1 mutations.

Keywords: Succinate dehydrogenase, Leukoencephalopathy, SDHAF1, Leigh syndrome, Complex II deficiency, Assembly factor

\section{Background}

Deficiency of complex II (succinate dehydrogenase, $\mathrm{SDH})$ is a rare cause of disordered oxidative phosphorylation (OXPHOS) and is associated with a wide range of clinical symptoms. Among our cohorts of more than 1200 patients with defects in OXPHOS we found only nine with biochemically proven deficiency of complex II.

In 2001 we reported a characteristic finding in localized in vivo cerebral proton magnetic resonance

\footnotetext{
* Correspondence: aohlenb@gwdg.de; kbrock@med.uni-goettingen.de ${ }^{\dagger}$ Equal contributors

'Department of Pediatrics and Pediatric Neurology, Georg August University, Robert Koch Str. 40, Göttingen 37075, Germany

Full list of author information is available at the end of the article
}

spectroscopy (MRS) in three patients from two unrelated families, two German sisters of Turkish origin (family A) and one Norwegian boy (family B), presenting with symptoms and MRI signs of leukoencephalopathy [1]. MRS revealed a prominent singlet at $2.40 \mathrm{ppm}$ in cerebral and cerebellar white matter originating from accumulated succinate in affected white matter. Biochemical investigations demonstrated isolated deficiency of complex II in muscle and fibroblasts of these patients.

Recently, homozygous mutations in SDHAF1, encoding a new LYR-motif protein, were detected in 2 families from Turkey and Italy with several children affected by infantile leukoencephalopathy with defective SDH [2,3].

We investigated whether SDHAF1 is mutated in our nine patients with complex II deficiency with either

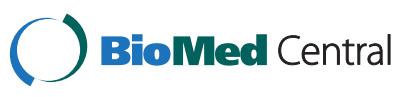


SDH-defective leukoencephalopathy or other, diverse clinical phenotypes without leukoencephalopathy.

\section{Patients and methods}

The Table 1 summarizes the clinical, neuroradiological, and biochemical features of five patients from three families with SDH-defective leukoencephalopathy and 4 unrelated patients with other clinical phenotypes of complex II deficiency. Details of clinical and neuroradiological features of patients \#1, \#2 and \#3 were described previously [1].

In family A, patients \#1 and \#2 were the second and fifth children of healthy, consanguineous (first cousins) German parents of Turkish origin belonging to a big pedigree where SDHAF1 mutations were previously described [2]. Both sisters presented with motor deterioration and spasticity in the $2^{\text {nd }}$ half of their first year of life. MRI of the brain revealed extensive T2hyperintensities in cerebral and cerebellar white matter, and cerebral proton MRS demonstrated accumulation of succinate. The elder sister died from multiorgan failure with severe lactic acidosis at age 18 months. Postmortem examination revealed histopathological features and topic patterns of a multifocal spongiform encephalomyelopathy consistent with Leigh syndrome [1]. The younger sister showed severe motor disability with marked spastic tetraparesis and relatively preserved cognitive abilities. She died at age 11 years.

In family B, patient \#3 was the first of three children of allegedly unrelated Norwegian parents coming from neighboring areas. With onset at 20 months increasing spasticity and clumsiness were observed. Cerebral MRI and proton MRS indicated a leukoencephalopathy with accumulation of succinate. Biochemical analysis of fibroblasts demonstrated an isolated deficiency of complex II. At present, at age 16 years, his main clinical feature is spastic paraplegia. He has suffered single epileptic seizures but has no preventive treatment. The cognitive

Table 1 Clinical, neuroradiological, biochemical and genetic features of five patients from three families with SDH-defective leukoencephalopathy and four unrelated patients with other, diverse phenotypes of complex II deficiency

\begin{tabular}{|c|c|c|c|c|c|c|c|c|c|c|}
\hline $\begin{array}{l}\text { Patient } \\
\text { (origin) }\end{array}$ & Sex & $\begin{array}{l}\text { Present } \\
\text { age }\end{array}$ & $\begin{array}{l}\text { Affected/ } \\
\text { unaffected } \\
\text { siblings }\end{array}$ & $\begin{array}{l}\text { Consanguinity } \\
\text { of parents }\end{array}$ & $\begin{array}{c}\text { Age } \\
\text { at onset }\end{array}$ & $\begin{array}{l}\text { Presenting } \\
\text { sign }\end{array}$ & $\begin{array}{l}\text { MRI, proton } \\
\text { MRS of } \\
\text { the brain }\end{array}$ & Postmortem & $\begin{array}{l}\text { Complex II } \\
\text { activity } \\
\text { measured in: } \\
\text { (SDH residual } \\
\text { activity } \\
\text { normalized } \\
\text { to CS) }\end{array}$ & $\begin{array}{l}\text { SDHAF1 } \\
\text { mutation }\end{array}$ \\
\hline $1(T)$ & $f$ & $\begin{array}{l}\text { Died at } \\
18 \mathrm{mo}\end{array}$ & $1(\# 2) / 2$ & + & $10 \mathrm{mo}$ & $\begin{array}{l}\text { Motor } \\
\text { regression }\end{array}$ & $\begin{array}{c}\text { Bilateral LE, } \\
\text { succinate peak }\end{array}$ & $\begin{array}{l}\text { Leigh } \\
\text { syndrome }\end{array}$ & $\begin{array}{c}\text { Muscle (46\%), } \\
\text { fibroblasts } \\
(24 \%)\end{array}$ & $\begin{array}{l}\text { c.164 G>C }{ }^{a} \\
\text { p.Arg55Pro }\end{array}$ \\
\hline $2(T)$ & $f$ & $\begin{array}{l}\text { Died at } \\
11 \text { yrs }\end{array}$ & $1(\# 1) / 2$ & + & $10 \mathrm{mo}$ & $\begin{array}{l}\text { Motor } \\
\text { regression }\end{array}$ & $\begin{array}{c}\text { Bilateral LE, } \\
\text { succinate peak }\end{array}$ & - & $\begin{array}{c}\text { Fibroblasts } \\
(74 \%)\end{array}$ & $\begin{array}{l}\text { c.164 G>C }{ }^{a} \\
\text { p.Arg55Pro }\end{array}$ \\
\hline $3(N)$ & $\mathrm{m}$ & 16 yrs & $-/ 2$ & Uncertain & $20 \mathrm{mo}$ & $\begin{array}{l}\text { Spasticity, } \\
\text { clumsiness }\end{array}$ & $\begin{array}{c}\text { Bilateral LE, } \\
\text { succinate peak }\end{array}$ & - & $\begin{array}{c}\text { Fibroblasts } \\
(16 \%)\end{array}$ & $\begin{array}{l}\text { c. } 22 C>T^{b} \\
\text { p.Gln } 8 X\end{array}$ \\
\hline $4(P)$ & $f$ & $\begin{array}{l}\text { Died at } \\
5 \text { yrs }\end{array}$ & $1(\# 5) / 1$ & + & $14 \mathrm{mo}$ & $\begin{array}{l}\text { Spasticity, } \\
\text { motor regression }\end{array}$ & $\begin{array}{c}\text { Bilateral LE, } \\
\text { succinate peak }\end{array}$ & - & $\begin{array}{l}\text { Lymphocytes } \\
(39 \%)\end{array}$ & $\begin{array}{c}\text { c. } 170 \mathrm{G}>\mathrm{A}^{\mathrm{b}} \\
\text { p.G57E }\end{array}$ \\
\hline $5(P)$ & $f$ & $3 \mathrm{yrs}$ & $1(\# 4) / 1$ & + & $4 \mathrm{mo}$ & Spasticity & $\begin{array}{c}\text { Bilateral LE, } \\
\text { succinate peak }\end{array}$ & - & $\begin{array}{l}\text { Lymphocytes } \\
\text { (58\%) }\end{array}$ & $\begin{array}{c}\text { c. } 170 \mathrm{G}>\mathrm{A}^{\mathrm{b}} \\
\text { p.G57E }\end{array}$ \\
\hline $6(\mathrm{G})$ & $\mathrm{m}$ & $15 \mathrm{yrs}$ & $-1-$ & - & $3 \mathrm{yrs}$ & $\begin{array}{c}\text { Exercise } \\
\text { intolerance }\end{array}$ & $\begin{array}{c}\text { Normal, } \\
\text { no succinate peak }\end{array}$ & - & $\begin{array}{c}\text { Muscle } \\
(55 \%)\end{array}$ & None \\
\hline $7(J)$ & $f$ & $\begin{array}{l}\text { Died at } \\
2 \text { yrs }\end{array}$ & $-1-$ & - & $18 \mathrm{mo}$ & $\begin{array}{c}\text { Acute liver } \\
\text { failure, liver } \\
\text { transplantation }\end{array}$ & - & - & $\begin{array}{l}\text { Liver } \\
(42 \%)\end{array}$ & None \\
\hline $8(J)$ & $f$ & 9 yrs & $-/ 2$ & - & birth & $\begin{array}{l}\text { Psychomotor } \\
\text { retardation, } \\
\text { muscle weakness, } \\
\text { hearing loss }\end{array}$ & Normal & - & $\begin{array}{l}\text { Muscle } \\
(45 \%)\end{array}$ & None \\
\hline $9(J)$ & $f$ & $7 \mathrm{yrs}$ & $-/-$ & - & birth & $\begin{array}{c}\text { Psychomotor } \\
\text { retardation, } \\
\text { muscle weakness, } \\
\text { hypotonia }\end{array}$ & Normal & - & $\begin{array}{l}\text { Muscle } \\
\text { (71\%) }\end{array}$ & None \\
\hline
\end{tabular}


function is tested to be within normal range. His fine motor skills and language function are good, and he is attending ordinary school with some facilitation. A follow-up cranial MRI performed at age 9 years showed leukoencephalopathy with supratentorial bilateral T2hyperintensities (Figure 1), largely unchanged compared with neuroimaging performed 5 years before [1].

In family $C$, patients \#4 and \#5 were the first and second of three daughters of consanguineous Palestinian parents. With onset at 14 and 4 months, respectively, they showed motor regression and spasticity. In patient \#4, best motor function was standing up, best mental function was speaking a few words. In patient \#5, best motor function was head control at 5 months, best social function was smiling at 3 months. In both girls MRI and proton MRS of the brain revealed bilateral leukoencephalopathy and accumulation of succinate. Complex II deficiency was demonstrated in muscle or lymphocytes or both. Patient \#4 died at age 5 years from pneumonia. Postmortem was not performed.

Additional four patients (\#6 to \#9) presented with other, diverse clinical features. Patient \#6 showed exercise intolerance and SDH-defective myopathy. He had normal cognitive abilities with very good performance at school as well as normal MRI and MRS of the brain. After initial normal development, patient \#7 suffered from acute liver failure requiring liver transplantation with fatal outcome at age 2 years. Psychomotor retardation with muscle weakness and hearing impairment were main clinical features of patient \#8. Patient \#9 showed psychomotor retardation as well as muscular hypotonia and weakness. In all of these four patients, complex II deficiency was demonstrated biochemically in muscle or liver. MRI of the brain was performed in patients \#6, \#8, and \#9 (with additional proton MRS of the brain in \#6) and did not reveal leukoencephalopathy or any other abnormalities.

\section{Genetic analysis}

Total genomic DNA was extracted from peripheral blood leukocytes by standard techniques. Primers for DNA amplification and sequencing were designed to cover exon 1 of SDHAF1 along with flanking segments (GenBank Reference No. NC_000019.9). Screening for

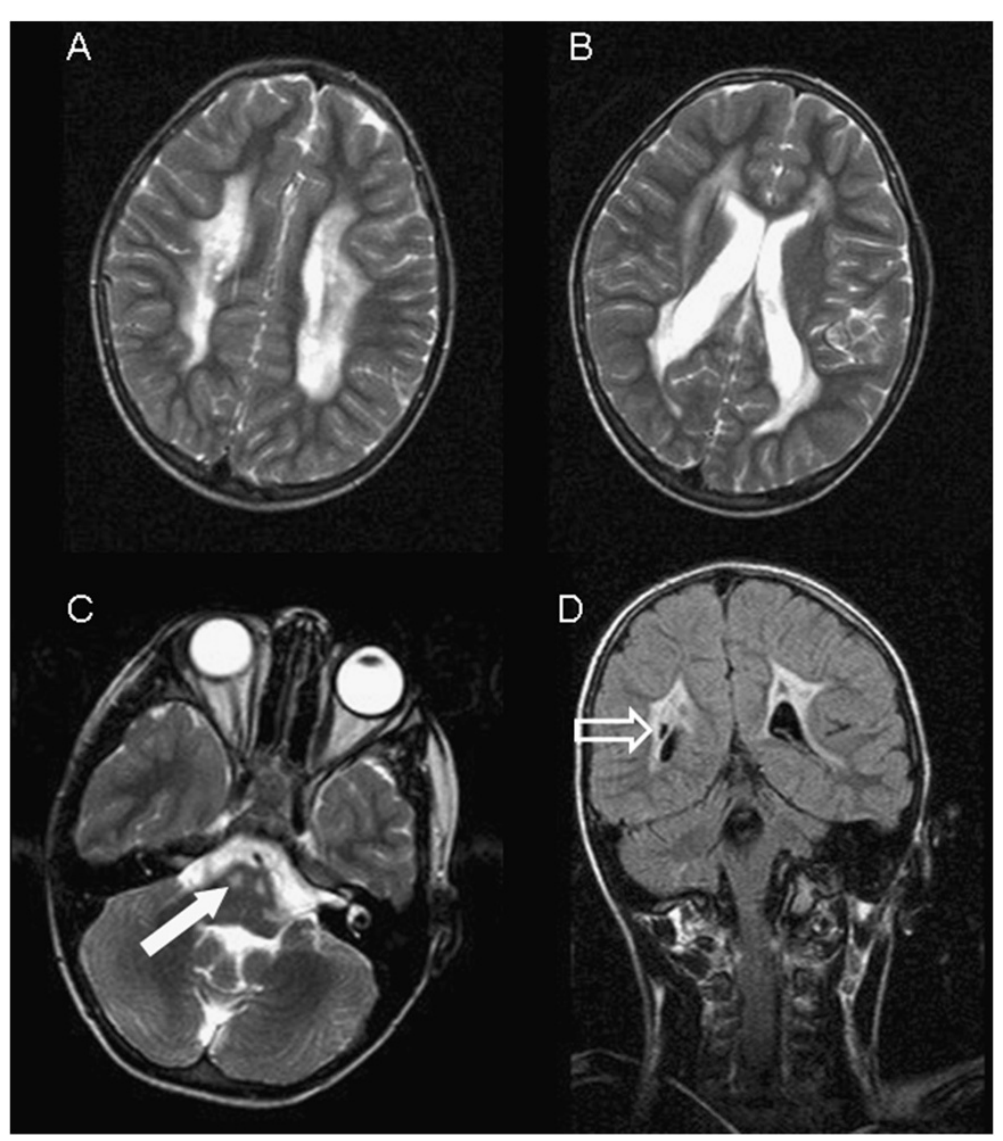

Figure 1 (A-C) Axial T2-weighted and (D) coronal FLAIR-weighted MR images of patient 3 at 9 years of age show widespread bilateral T2-hyperintensities in cerebral periventricular white matter. Involvement of the pons (C, full white arrow) and cystic lesions (D, open arrow) are visible. Peripheral U-fibers are spared. Lesions are largely unchanged compared to neuroimaging at age 4 years'. 
sequence variants was performed using the BigDye ${ }^{\mathrm{TM}}$ Terminator Ready Reaction chemistry on an ABI PRISM 3100 Avant genetic analyzer (Applied Biosystems, Darmstadt, Germany). All identified mutations were confirmed by direct sequencing of two different PCR amplification products on forward and reverse strands. Primer sequences as well as PCR and sequencing conditions are available on request. Informed consent was obtained for each patient from the parents. The Institutional Review Board approved the study.

\section{Results}

Patients \#1 and \#2, siblings of Turkish origin, were homozygous for a missense mutation c.164 G > C, corresponding to p.Arg55Pro, with both unaffected parents being heterozygous for the mutation.

We found a homozygous c. $22 \mathrm{C}>\mathrm{T}$ nonsense mutation in patient \#3 of Norwegian origin predicted to result in a premature stop of translation (p.Gln8X). Two healthy siblings as well as the unaffected parents were heterozygous carrier for this variant.

In patients \#4 and \#5, siblings from consanguineous parents of Palestinian origin, a missense mutation c.170 G > A, corresponding to p.Gly57Glu was detected. This mutation affects the same highly conserved residue, Gly57, as the mutation Gly57Arg reported previously in an Italian family [2]. This observation indicates a fundamental role for Gly57 for the function of SDHAF1.

Molecular analysis of the coding sequence as well as of adjacent promoter and 3/UT regions revealed no sequence alterations in patients \#6 to \#9.

\section{Discussion}

Mutation analysis of the SDHAF1 gene revealed mutations in five patients with SDH-defective infantile leukoencephalopathy. The missense mutation detected in patients \#1 and \#2 was reported previously in a large multiconsanguineous kindred of Turkish origin with several affected children [2,3]. Family history of the siblings described here (patients \#1 and \#2) indicates common ancestry with those patients. The homozygous nonsense mutation demonstrated in patient \#3 and the homozygous missense mutation detected in patients \#4 and \#5 were not reported before.

Succinate dehydrogenase participates in the electron transfer in the respiratory chain and in succinate catabolism in the Krebs cycle and consists of four subunits, all encoded by the nuclear genome [4]. Isolated complex II deficiency is a relatively rare cause of mitochondrial disease compared to other respiratory chain defects, but is associated with a wide range of clinical features [5]. Mutations in the four genes, $S D H-A,-B,-C,-D$, have been reported, with remarkably diverse phenotypes. Mutations in the SDHA gene were found to be associated with Leigh syndrome [6], late onset neurodegenerative disease [7] and dilated cardiomyopathy [8]. Heterozygous germline mutations in $S D H A, S D H B, S D H C$, and $S D H D$ cause hereditary paragangliomas and pheochromocytomas [9], and germline mutations in $S D H B$ and $S D H C$ were found to be associated with gastrointestinal stromal tumors [4]. Recently, a mitochondrial encephalopathy was reported to be caused by SDHD mutations [10].

Whereas an increasing number of assembly factors have been identified for complex I, III, and cytochrome oxidase, little was known concerning the assembly of complex II. Recently two genes involved in this process were detected in humans, and the first, termed SDHAF1, was found by linkage analysis in two families with SDHdefective infantile leukoencephalopathy [2]. Yeast experimentation indicated that the protein encoded by this gene is required for the stable assembly and full function of the SDH complex. The protein was thus termed SDH assembly factor 1 (SDHAF1) [2].

In the same year, mutations in the SDHAF2 (SDH5) gene encoding a protein necessary for the flavination of the subunit SDHA were detected in patients with paraganglioma [10]. The cause of such diverse phenotypes associated with defective assembly factors of complex II remains enigmatic to date.

Our results confirm the pathogenicity of SDHAF1 mutations in infantile leukoencephalopathy due to defective succinate dehydrogenase. Our patients with complex II deficiency not associated with leukoencephalopathy but with other, diverse clinical phenotypes including myopathy with exercise intolerance, acute liver failure, psychomotor delay, muscle weakness, and hearing impairment did not carry a SDHAF1 mutation. Further studies will clarify whether infantile leukoencephalopathy with accumulation of succinate, readily detectable by in vivo proton MR spectroscopy of the brain, is pathognomonic for SDHAF1 deficiency.

To date, clinical features comprising motor regression with spasticity and neuroradiological features including bilateral leukoencephalopathy with elevated succinate on cerebral proton MRS are the suggestive findings pointing to a SDHAF1 mutation.

Treatment with riboflavin was found to be effective in selected mitochondrial disorders, including SDH deficiency [3]. In our cohort, riboflavin treatment was applied in patients \#2, \#4, and \#5 (SDHAF1 mutations) as well as \#6 (SDH-defective myopathy with exercise intolerance). Riboflavin treatment resulted in no discernable effect in the 3 patients with SDHAF1 mutations. Patient \#6 had clear benefit from this treatment with markedly prolonged motor endurance.

The clinical course in our five patients with SDHAF1 mutations is strikingly diverse. Patients \#1, \#2, and \#4, all carrying missense mutations, died at age 18 months, 
11 years, and 5 years, respectively, with histopathological features of Leigh syndrome in one of them. In contrast, patient \#3, who carries a stop mutation, follows a milder course with spastic paraparesis as the main clinical feature 14 years after onset and stable white matter changes on MRI over many years. We hypothesize that an atypical starting codon could be present resulting in synthesis of a partially functional protein. Further studies are needed to elucidate the pathomechanism of this stop mutation. This variation points to influential further genetic or epigenetic factors shaping the phenotype of defective complex II assembly due to mutated SDHAF1.

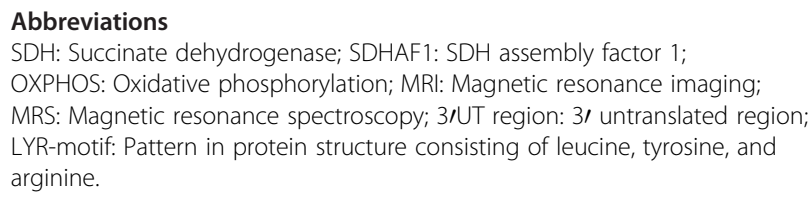

\section{Competing interests}

The authors declare that they have no competing interests.

\section{Authors' contributions}

$\mathrm{AO}$ carried out the molecular genetic studies. SE, AB, JS contributed with clinical data. AS carried out the biochemical investigations. OE contributed with clinical and genetic information and interpretation of data. JG participated in the design of the study and interpretation of data. KB conceived of the study, provided clinical information and drafted the manuscript. All authors participated in finalizing the manuscript and read and approved the final manuscript.

\section{Acknowledgements}

We wish to thank all patients and their families for their generous help. Supported by the Deutsche Forschungsgemeinschaft (GA354/9-1) and the Bundesministerium für Bildung und Forschung (BMBF) through the German Leukodystrophy Network.

\section{Author details}

'Department of Pediatrics and Pediatric Neurology, Georg August University, Robert Koch Str. 40, Göttingen 37075, Germany. ${ }^{2}$ Pediatric Neurology Unit, Hadassah, Hebrew University Medical Center, Jerusalem, Israel. ${ }^{3}$ Department of Pediatric Medicine, Child Habilitation Unit, Ålesund Hospital, Ålesund, Norway. ${ }^{4}$ Department of Pediatrics, Drammen Sykehus, Drammen, Norway. ${ }^{5}$ The Department of Genetic and Metabolic Diseases, Hadassah, Hebrew University Medical Center, Jerusalem, Israel.

Received: 18 April 2012 Accepted: 19 September 2012

Published: 20 September 2012

\section{References}

1. Brockmann K, Bjornstad A, Dechent P, Korenke CG, Smeitink J, Trijbels JM, Athanassopoulos S, Villagran R, Skjeldal OH, Wilichowski E, Frahm J, Hanefeld F: Succinate in dystrophic white matter: a proton magnetic resonance spectroscopy finding characteristic for complex II deficiency. Ann Neurol 2002, 52:38-46.

2. Ghezzi D, Goffrini P, Uziel G, Horvath R, Klopstock T, Lochmüller H, D'Adamo P, Gasparini P, Strom TM, Prokisch H, Invernizzi F, Ferrero I, Zeviani M: SDHAF1, encoding a LYR complex-II specific assembly factor, is mutated in SDH-defective infantile leukoencephalopathy. Nat Genet 2009, 41:654-656.

3. Bugiani M, Lamantea E, Invernizzi F, Moroni I, Bizzi A, Zeviani M, Uziel G: Effects of riboflavin in children with complex II deficiency. Brain Dev 2006, 28:576-581.

4. Rutter J, Winge DR, Schiffman JD: Succinate dehydrogenase - Assembly, regulation and role in human disease. Mitochondrion 2010, 10:393-401.

5. Rustin P, Rötig A: Inborn errors of complex II-unusual human mitochondrial diseases. Biochim Biophys Acta 2002, 1553:117-122.
6. Bourgeron T, Rustin P, Chretien D, Birch-Machin M, Bourgeois M, ViegasPéquignot $E$, Munnich $A$, Rötig A: Mutation of a nuclear succinate dehydrogenase gene results in mitochondrial respiratory chain deficiency. Nat Genet 1995, 11:144-149.

7. Taylor RW, Birch-Machin MA, Schaefer J, Taylor L, Shakir R, Ackrell BA, Cochran B, Bindoff LA, Jackson MJ, Griffiths P, Turnbull DM: Deficiency of complex II of the mitochondrial respiratory chain in late-onset optic atrophy and ataxia. Ann Neurol 1996, 39:224-232.

8. Levitas A, Muhammad E, Harel G, Saada A, Caspi VC, Manor E, Beck JC, Sheffield V, Parvari R: Familial neonatal isolated cardiomyopathy caused by a mutation in the flavoprotein subunit of succinate dehydrogenase. Eur J Hum Genet 2010, 18:1160-1165.

9. Burnichon $N$, Brière JJ, Libé R, Vescovo L, Rivière J, Tissier F, Jouanno E, Jeunemaitre X, Bénit P, Tzagoloff A, Rustin P, Bertherat J, Favier J, GimenezRoqueplo AP: SDHA is a tumor suppressor gene causing paraganglioma. Hum Mol Genet 2010, 19:3011-3020.

10. Hahn D, Schaller A, Jackson CB, Häberli A, Gallati S, Vella S, Nuoffer JM: First report of a mitochondrial encephalopathy associated to SDHD mutations. J Inherit Metab Dis 2010, 33(Suppl 1):S75.

doi:10.1186/1750-1172-7-69

Cite this article as: Ohlenbusch et al:: Leukoencephalopathy with accumulated succinate is indicative of SDHAF1 related complex \| deficiency. Orphanet Journal of Rare Diseases 2012 7:69.

\section{Submit your next manuscript to BioMed Central and take full advantage of:}

- Convenient online submission

- Thorough peer review

- No space constraints or color figure charges

- Immediate publication on acceptance

- Inclusion in PubMed, CAS, Scopus and Google Scholar

- Research which is freely available for redistribution 